\title{
Tax Audits and Tax Compliance in Rivers State Internal Revenue Service, Nigeria
}

\author{
ThankGod, C. Agwor PhD* Ajinwo, Bright \\ Department of Accountancy, Faculty of Management Sciences, Rivers State University, Port Harcourt
}

\begin{abstract}
This study examined the relationship between tax audits with the empirical referents of desk audit, field audit and tax compliance with its measures of taxpayers registration, filing of tax return and penalties in Rivers State Internal Revenue Service. Tax audits as emerging concepts has suffered from scarcity of empirical evidence in Rivers State. Research hypotheses were formulated to test the relationship between tax audits and tax compliance. Copies of Questionnaire were distributed. The data that was obtained via survey instruments were analyzed using the descriptive statistical method to test for the mean, Rho analysis. Reliability test was conducted using Cronbach Alpha reliability with the scores of the variables of 0.7 . The hypotheses were tested using Pearson's Product Moment Correlation (PPMC) and regression analysis. From the analysis, the result shows that there is a significant relationship between empirical referent of tax audits and the measures of tax compliance. The study also found that there is a significant association between desk audits and filing of tax returns. Also desk audit is significantly correlated to penalties. Other results show that there is significant association between field audits and filing of tax returns, field audit and penalties also have a significant association. It was also found that adequate manpower does have mediating influence in the association between tax audits and tax compliance. Consequently, the study concludes thus, organizations prefers desk audits to field audits because field audits reveals more detailed work and encourages the provision of more documents by the taxpayer. The desk audit is more convenient for both the revenue authority and the taxpayer because field audit entails elaborate job to be performed by the Revenue authority. The study recommends that tax audits should be carried out on regular intervals, by this compliance rate will increase if tax audit is administered and the revenue realized is judiciously used. Tax audits should include desk audit and field audit. Adequate personnel should be engaged to carry out tax audits. Desk audit for the sake of convenience should be preferred to field audit and finally, companies that fall within the tax net should comply to avoid penalties.
\end{abstract}

Keywords: Tax, Tax audits, Tax Compliance, Internal revenue Service

DOI: $10.7176 /$ RJFA/11-16-13

Publication date:August $31^{\text {st }} 2020$

\section{Introduction}

Tax audit is an examination into the financial records of taxpayers by the revenue authorities with the sole aim of identifying that the exact or correct amount of tax has been paid by the taxpayers to the government in a particular year of assessment in relation to the activities of the taxpayers. The relevant tax authorities responsible for tax audit are the Federal Inland Revenue Service (FIRS) for limited liability companies and State Board of Internal Revenue (SBIR) for enterprises. Tax audit also serve as additional audit to the original statutory audit and it is performed by the officials of the tax authority. Tax audit differs from the statutory audit with respect to the requirements of the Company and Allied Matters Act (CAMA) 1990 (as amended). There are outlined criteria for companies to be selected for tax audit which may include the following: nil tax returns, refund cases, persistent losses, low tax yield, non-submission of returns, fraud or evasion, suspicion for tax avoidance, transfer mispricing, thin capitalization and sometimes when taxpayers request for tax clearance certificate (TCC) among others (Bitrus, Okonkwo \& Oyedokun 2014).

Okonkwo (2014), concluded that tax audit exercise is a very important compliance tool in most jurisdictions of the world. Tax audit has contributed tremendously in creating awareness amongst stakeholders in strengthening of the self-assessment tax system, bringing numerous taxpayers into the tax net, it increases generation of tax revenue and it also checks various abuses in the tax system. Tax audit is carried out to ensure a true and fair view of the business records for tax purposes, hence the officials of the tax audit is responsible to ensure that the amount reported is correct and the amount of tax liability is being paid in accordance with the rules, regulations and tax laws.

This extant study did not consider the association between tax audit and tax compliance particularly in Rivers state. This study therefore, investigates the relationship between tax audit and tax compliance in Rivers State. It is worthy of note that numerous studies which are of foreign and domestic origin revealed that, tax audits and tax compliance have not been substantially carried out in Rivers State. The few available in literature are of larger scope. In order to close this gap in knowledge and expand the knowledge base in this area of study, this research work becomes necessary.

Tax audit which is an examination by the tax authorities into the financial records of a taxpayer is a crucial 
and important exercise in making sure that compliance by the taxpayer is adhere to and that the audit also enhances the generation of revenue in the jurisdiction in which the tax audit is carried out. It involves careful examination of records of the tax-payers and identify that the actual amount of payable tax that is to be paid is paid by the taxpayer as at when due and considering the nature of the taxpayers business. The idea of tax audit is not too far from tax compliance as tax compliance refers to the degree to which the taxpayers voluntarily comply with his or her tax liabilities. In other to ensure total compliance, knowing that taxpayers will always like to evade taxes, tax audit is introduced in ensuring that the correct amount of tax have been paid by the taxpayer and as at when due.

Therefore, the purpose of the study is to ascertain the correlation between tax audit and tax compliance in Rivers State, Nigeria.

\section{Literature Review}

Niu (2010) in his study found a positive relationship between the audit and the voluntary compliance. The finding suggests that the productivity of the audit may be under estimated in many studies in available literature. Besides considering direct audit collections, there should be focus on the audit impact on the voluntary compliance. For this reason, the finding may provide tax professionals and Revenue authorities with incentives to strengthen the audit power and to better structure their audit organization in other to generate more revenue for the state. Niu (2010) Historical population data of a New York State economic sector were used in the study, instead of experimental data or randomly selected sample data often used in literature. The results of both Ordinary Least Squares (OLS) and Time Series Cross Section (TSCS) autoregressive modeling methods, suggest that after an audit, a firm would report a higher sales growth rate.

Kwon (2004) study in Korea observed that a more thorough analysis to evaluate and determine tax culture for the study of tax audit and tax compliance. Tax audit is of three types ,Badara (2012) opined that these three types of audit include the random tax audit, cut-off tax audit and conditional tax audit. The random tax audit scheme simply provides each self-assessment of income an equal opportunity of being chosen for verification by an audit. Cut-off audit scheme, the resources of audit are employed to verify if the reports of the tax payers are reporting the lowest income levels. The conditional audit scheme requires in addition to the reported income, sources of information representing a noisy signal of tax payers ${ }^{\text {ee }}$ thorough income earning potentials.

Badara, (2012) copies of questionnaire distributed to forty-eight (48) respondents using descriptive statistics. The result shows that the Relevant Tax Authority (RTA) employed tax audit in order to achieve target revenue, it is also worthy to note that tax audit reduce the problems of evasion of tax, that tax payers will not ordinarily cooperate with tax audit personnel during the audit exercise. There are several theoretical and empirical studies on tax audit and tax compliance in literature that agrees with the argument of Badara, (2012)

Alm and McKee, (2006) in their quest investigates the application of experimental methods to examine the individual compliance responses to a "certain" probability of audit, and concluded that the compliance rate will increase if an individual is aware that he or she will be audited and the rate falls if he or she is aware that he will not be audited. Slemrod et al, (2001) after the examination of some taxpayers that were randomly selected, informed the taxpayers that their filling will be "closely examined"e and found evidence of taxpayers" behavior changes in response to an increased probability of audit, although the responses were not uniform among different groups of taxpayers.

Mittone (2006) advance that when audit is done earlier, it is more effective in the life of a taxpayers"e "tax life" and it also increases compliance than later audits. Also Kastlunger et al, (2009) study of experimental research also opined that, although the effectiveness of audits and fines cannot be completely confirmed, early audit in taxpayers, "tax life" have a positive impact on tax compliance. Kleven et al (2010) argued that 40,000 individual tax filers using experimental design and randomization test and SKAT's Business object Database with ordinary least square. Their research reveals that tax evasion rate is small for those income that are subject to third party reporting, but substantial for self-assessed income; marginal tax rates have a positive impact on tax evasion, but the effect is reasonably small; prior audits substantially increase self- assessed income and threat of audit letters also have a significant effects on self- reported income, and the size of this effect depends positively on audit probability expressed in the letter. Hyun (2005) who used Japan \& Korea as a case study, using world value survey dataset and descriptive statistics and multiple regression for analysis, Opined that Japan has a higher level of tax culture than that of Korea; and that the legal system is relatively more important factor to determine the level of tax culture which eventually affects the level of compliance. Plumley et al (1996) Dataset from 1991-2001 using Ordinary Least Square. The result revealed that a significant effects are attributable to many tax policy and tax administration parameters; including: audits; third party information documents; the issuance of targeted non-filer notices; criminal tax convictions; marginal tax rates.

\section{Methodology}

This study adopted explanatory and cross- sectional approaches. Specifically, the correlational research design 
was used for this study to generate data and explain relationship among the variables under investigation. The population of this study comprised of five selected companies and their taxpayers with total employees of 379 , that actually comply to tax and file returns in the Rivers State Internal Revenue Service. However, the population scope is within a unit that can be controlled.

The sample size therefore was determined using the Taro Yamen's formula. It was $\mathrm{n}=195$. Data collected were analyzed using descriptive statistics, excel software was also used in transforming the variables into formats suitable for analysis, after which statistical package for the social sciences (SPSS) current version 22.0 was used to analyze the data. The strength of relationship between the independent and dependent variables was ascertained using the Pearson's Product Moment Correlation Coefficient (PPMC).

\section{Results}

Table 1: Correlation Analysis (desk audit and filing of tax returns) Correlations

\begin{tabular}{|c|c|c|c|c|c|}
\hline & & & & $\begin{array}{l}\text { Desk } \\
\text { Audit }\end{array}$ & $\begin{array}{l}\text { Filing of tax } \\
\text { Returns }\end{array}$ \\
\hline \multirow[t]{6}{*}{ Spearman's rho } & \multirow{3}{*}{\multicolumn{2}{|c|}{ Desk Audit }} & $\begin{array}{l}\text { Correlation } \\
\text { Coefficient }\end{array}$ & 1.000 & $.712^{* *}$ \\
\hline & & & Sig. (2-tailed) & & .000 \\
\hline & & & $\mathrm{N}$ & 138 & 138 \\
\hline & \multirow[t]{3}{*}{$\begin{array}{l}\text { Filing } \\
\text { returns }\end{array}$} & $\operatorname{tax}$ & $\begin{array}{l}\text { Correlation } \\
\text { Coefficient }\end{array}$ & $.712^{* *}$ & 1.000 \\
\hline & & & Sig. (2-tailed) & .000 & . \\
\hline & & & $\mathrm{N}$ & 138 & 138 \\
\hline
\end{tabular}

**. Correlation is significant at the 0.01 level (2-tailed).

The table above shows that the Spearman's correlation coefficient $(\mathrm{r})=0.712^{* *}$, which is high value, implying that a strong relationship exists between desk audit and filing of tax returns. The positive sign of the correlation coefficient means that positive relationships exist between them. This means that increase in desk audit is associated with an increase in filing of tax returns.

\section{Test of Hypothesis 1}

Ho1: There is no significant relationship between desk audit and filing of tax returns.

The table show that the probability/significant value is 0.000 , this value is less than 0.05 level of significance, hence the null hypothesis $\left(\mathrm{H}_{\mathrm{O} 1}\right)$ is rejected with the conclusion that a significant relationship exist between desk audit and filing of tax returns. The coefficient of determination $\left(\mathrm{r}^{2}\right)$ is 0.506944 or $50.69 \%$. This indicates that desk audit accounts for $50.69 \%$ of filing of tax returns.

Table 2: Correlation Analysis (Desk audit and Taxpayers registration)

\section{Correlations}

\begin{tabular}{lllll}
\hline & & \multicolumn{1}{c}{$\begin{array}{c}\text { Desk } \\
\text { audit }\end{array}$} & \multicolumn{1}{c}{ Taxpayers registration } \\
\hline Spearman's rho & Desk audit & $\begin{array}{l}\text { Correlation } \\
\text { Coefficient }\end{array}$ & 1.000 & $.581^{* *}$ \\
& & $\begin{array}{l}\text { Sig. (2-tailed) } \\
\text { N }\end{array}$ &. & .000 \\
& Taxpayers & Correlation & $.581^{* *}$ & 1.000 \\
& Cogistration & Coefficient & .000 &. \\
& & Sig. (2-tailed) & 138 & 138 \\
& & N & &
\end{tabular}

**. Correlation is significant at the 0.01 level (2-tailed).

The above table explains that the Spearman's correlation coefficient $(r)=0.581 * *$, which is high value, implying that a moderate relationship exists between desk audit and taxpayers registration. The positive sign of the correlation coefficient means that positive relationships exist between them. That is to say, an increase in taxpayers' registration is associated with an increase in desk audit.

\section{Test of Hypothesis 2}

Ho2: There is no significant relationship between desk audit and taxpayers registration

Table 2 showed that the probability/significant value is 0.000 , this value is less than 0.05 level of significance, hence the null hypothesis $\left(\mathrm{H}_{\mathrm{O} 2}\right)$ is rejected with the conclusion that a significant relationship exist between desk audit and taxpayers registration. The coefficient of determination $\left(\mathrm{r}^{2}\right)$ is 0.337561 or $33.76 \%$. This indicates that desk audit accounts for $33.76 \%$ of taxpayers' registration. 
Table 3: Correlation Analysis (Desk audit and penalties)

\section{Correlations}

\begin{tabular}{lllll}
\hline & & & Desk audit & Penalties \\
\hline Spearman's rho & Desk audit & Correlation Coefficient & 1.000 & $.667^{* *}$ \\
& & Sig. (2-tailed) &. & .000 \\
& Penalties & $\mathrm{N}$ & 138 & 138 \\
\cline { 3 - 4 } & & Correlation Coefficient & $.667^{* *}$ & 1.000 \\
& Sig. (2-tailed) & .000 &. \\
& $\mathrm{~N}$ & 138 & 138 \\
\hline
\end{tabular}

**. Correlation is significant at the 0.01 level (2-tailed).

The above Table explains that the Spearman's correlation coefficient $(r)=0.667^{* *}$, this value is high, implying that a strong relationship exists between desk audit and penalties. The positive sign of the correlation coefficient means that positive relationships exist between them. That is to say that an increase in penalties is associated with an increase in desk audit.

\section{Test of Hypothesis 3}

Ho3: $\quad$ There is no significant relationship between desk audit and penalties

Table 3 indicates that the probability/significant value is 0.000 , this value is less than 0.05 level of significance, hence the null hypothesis $\left(\mathrm{H}_{\mathrm{O} 3}\right)$ is rejected with the conclusion that a significant relationship exist between desk audit and penalties. The coefficient of determination $\left(\mathrm{r}^{2}\right)$ is 0.444889 or $44.49 \%$. This indicates that desk audits accounts for $44.49 \%$ of penalty.

\section{Table 4. Correlation Analysis (Field audit and Filing of tax returns)}

\section{Correlations}

\begin{tabular}{lllll}
\hline & & $\begin{array}{l}\text { Field } \\
\text { audit }\end{array}$ & $\begin{array}{l}\text { Filing of tax } \\
\text { Returns }\end{array}$ \\
\hline Spearman's rho & Field audit & Correlation Coefficient & 1.000 & $.656^{* *}$ \\
& & Sig. (2-tailed) &. & .000 \\
& & $\mathrm{~N}$ & 138 & 138 \\
\cline { 3 - 5 } & Filing of tax & Correlation Coefficient & $.656^{* *}$ & 1.000 \\
& Returns & Sig. (2-tailed) & .000 &. \\
& & $\mathrm{~N}$ & 138 & 138 \\
\hline
\end{tabular}

**. Correlation is significant at the 0.01 level (2-tailed).

Table 4 above explains that the Spearman's correlation coefficient $(r)=0.656^{* *}$, this value is high, implying that a strong relationship exists between field audit and filing of tax returns. The positive sign of the correlation coefficient means that positive relationships exist between them. That is to say that an increase in filing of tax returns is associated with an increase in field audit.

\section{Test of Hypothesis 4}

Ho4: $\quad$ There is no significant relationship between field audit and filing of tax returns

Table 4 shows that the probability/significant value is 0.000 , this value is less than 0.05 level of significance, hence the null hypothesis $\left(\mathrm{H}_{\mathrm{O}}\right)$ is rejected with the conclusion that a significant relationship exist between field audit and filing of tax returns. The coefficient of determination $\left(\mathrm{r}^{2}\right)$ is 0.430336 or $43.03 \%$. This indicates that field audit accounts for $43.03 \%$ of filing of tax returns.

Table 5 : Correlation Analysis (Field audit and Taxpayers registration)

\section{Correlations}

\begin{tabular}{|c|c|c|c|c|}
\hline & & & $\begin{array}{l}\text { Field } \\
\text { audit }\end{array}$ & Taxpayers registration \\
\hline \multirow[t]{6}{*}{ Spearman's rho } & \multirow[t]{3}{*}{ Field audit } & $\begin{array}{l}\text { Correlation } \\
\text { Coefficient }\end{array}$ & 1.000 & $.568^{* *}$ \\
\hline & & Sig. (2-tailed) & . & .000 \\
\hline & & $\mathrm{N}$ & 138 & 138 \\
\hline & \multirow[t]{3}{*}{ Taxpayers registration } & $\begin{array}{l}\text { Correlation } \\
\text { Coefficient }\end{array}$ & $.568^{* *}$ & 1.000 \\
\hline & & Sig. (2-tailed) & .000 & . \\
\hline & & $\mathrm{N}$ & 138 & 138 \\
\hline
\end{tabular}

**. Correlation is significant at the 0.01 level (2-tailed).

The above table explains that the Spearman's correlation coefficient $(r)=0.568^{* *}$, this value is high, implying that a moderate relationship exists between field audit and taxpayers registration. The positive sign of the correlation coefficient means that positive relationships exist between them. That is to say that an increased in taxpayers registration is associated with an increase in field audit. 


\section{Test of Hypothesis 5}

Ho5: There is no significant relationship between field audit and taxpayers registration.

The table shows that the probability/significant value is 0.000 . this value is less than 0.05 level of significance, hence the researcher rejects the null hypothesis $\left(\mathrm{H}_{05}\right)$ and concludes that a significant relationship exist between field audit and taxpayers registration. The coefficient of determination $\left(\mathrm{r}^{2}\right)$ is 0.322624 or $32.26 \%$. This indicates that field audit accounts for $32.26 \%$ of taxpayers' registration.

\subsection{Discussion of Findings}

The study revealed that a significant relationship exist between tax audits and the tax compliance. This implies that tax audits significantly affects tax compliance. The studied carried out by Nui (2010), was in agreement, hence a positive relationship exist between tax audits and voluntary compliance.

Kwon (2004) also carried out a study, after thorough analysis to evaluate tax culture for the study of the audits and tax compliance, he opined that tax audits is of three types which includes random tax audits, cut-off tax audits and conditional tax audits, while Badara (2012), investigation elaborated that the random tax audits simply provides each self assessment of income and equal opportunity of being chosen for verification by the audit team. Cut-off audit scheme means that the resources of audit are employed to verify if the reports of the tax payers are reporting the lowest income levels. The conditional audit scheme requires in addition to the reported income, the sources of the information representing taxpayers income earnings potential. This studies revealed that a significant relationship exist between tax audits and tax compliance.

Alm and Mckee (2006), in their quest investigated the application of experimented methods to examine the field audit and individual tax compliance and concluded that compliance rate will increase if individual taxpayers are aware that they will be audited and decrease if they are aware that they will not be audited. Hence positive relationships exist between field audit and tax compliance.

In a nutshell, there is a significant relationship between field audit and penalties, which implies field audit significantly affects penalties .This was in agreement with the study of Mittone (2006), and hence a positive relationship exist between field audits and penalties.

\section{Conclusion}

The major objective of this investigation is to check the level of compliance that could be reached when tax audits is carried out. From the analysis, the data gathered provides answers to the research questions and the testing of the hypotheses.

The study also shows the relationship between tax audits and tax compliance, it is evidence that there is strong compliance rate when tax audits is been carried out.

It was also observed that companies or organizations prefer desk audit to field audit, as desk audit is more convenient to organizations compared to field audit which involves a detailed and elaborate work to be performed by the tax authorities which exposes more of the records of the taxpayer and is also time consuming.

Conclusively, there is a significant influence between tax audits and tax compliance, in the sense that tax audits increases the level of compliance, and for tax audits to be efficient and reliable, adequate, experience and professional personnel should be employed to carry out the task. Based on the discoveries made in this endeavour or from the assertions drawn, the following recommendations are presented ; (1)Tax audits should be carried out on regular intervals to ensure compliance,(2)Adequate and qualified personnel should be employed to carry out tax audits, so that the aim of tax audits will not be defeated,(3)Tax audits which includes desk and field audit, can also include in special cases sectorial and zonal audits,(4)For convenient sake, desk audit is preferred both by tax authority and tax payers,(5)Compliance rate will increase if tax audit is administered and the revenue realized from audit is judiciously utilized and (6) Organizations that fall within the tax nets should as a matter of obligatory obedience voluntarily comply to tax to avoid being penalized.

\section{REFERENCES}

Adams, C. (2001). For Good and Evil; The impact of Taxes on the Course of Civilization, U. S.A; Madison Publishers.

Adams, S. (2012).The Wealth of Nations; London; Everyman's Library Ltd.

Adedeji, T. O., \&Oboh, C. S. (2012).An empirical analysis of tax leakages and economic.Income Tax Compliance of Smes in Rivers State.Journal of Research in Business andManagement, 5(2), 40-51.

Adediran, S. A., Alade, S. O., \&Oshode, A. A. (2013). The impact of tax audit and investigation on revenue generation in Nigeria. European J. Bus. Manage., 5 (26).

Adefila, J.J. (2008) Research Methodology in Behavioural Sciences, Ilorin, Evidence (Nig) Ventures Publisher.

AdesinaO.O. (2005) Auditing and Investigations Theory and Practice Mindex Publishing Company Limited, Nigeria

Aguolu, O. (2007). Taxation and Tax Management in Nigeria.Enugu: Meridian Associates. 
Aguolu,O. (2004). Taxation and Tax Management in Nigeria, 3rd Edition, Enugu; Meridan Associates.

Ajzen, I. (1991). The theory of planned behavior.Organizational Behavior and Human Decision Processes, $50(2), 179-211$

Ajzen, I. (2002). Perceived Behavioural Control, Self-Efficiency, Locus of Control, and the Theory of Planned Behaviour", Journal of Applied Social Psychology, 32(4): 665-683.

Ajzen, I., \&Fishbein, M. (2012). Attitude-behavior relations: A theoretical analysis and review of empirical research. Psychological Bulletin, 84(5), 888-918.

Ajzen, I., \&Fishbein, M. (2009).Understanding attitudes and predicting social behavior. Prentice-Hall.

Akinbuli, S.F., 2010. The Effect of Audit Expectation Gap on the Work of Auditors, the Profession and Users of Financial Information. The Nigerian Accountant, 43(4): 37-47.

Akintoye, I. R., \&Tashie, G. A. (2013).The effect of tax compliance on economic growth and development in Nigeria.West-Africa. British Journal of Arts and Social Sciences.2(2), 222-232.

Blanthorne C. and Kaplan S. (2008).An egocentric model of the relations among the opportunity to underreport, social norms, ethical beliefs, and underreporting behavior".Accounting, Organizations \& Society, 33: 684703.

Bobek, D. D., \& Hatfield, R. C. (2003).An investigation of the theory of planned behavior and the role of moral obligation in tax compliance.Behavioral RESEARCH in Accounting, 15(1), 13-38.

Boll, K. (2013). Mapping tax compliance: Assemblages, distributed action and practices: A new way of doing tax research. Critical Perspectives on Accounting.

Braithwaite, V. A. (2003). Taxing Democracy: Understanding Tax Avoidance and Evasion.Ashgate Publishing, Ltd.

Elffers, H., Robben, H. S. J., \&Hessing, D. J. (1992).On measuring tax evasion.Journal of Economic Psychology, 13(4), 545-567

Elffers, H., Weigel, R. H., \&Hessing, D. J. (2009).The consequences of different strategies for measuring tax evasion behavior.Journal of Economic Psychology, 8(3), 311-337

Eriksen, K., \&Fallan, L. (1996).Tax knowledge and attitudes towards taxation; A report on a quasiexperiment.Journal of Economic Psychology, 17(3), 387-402.

Farayola, G.O. (2001) Guide to Nigerian Taxation, Ikeja, All Group Nigeria Limited Publishers.FGN,(1993)Personal Income Tax Act PITA (1993) as amended till date

Houston J, Tran A (2001).A Survey of Tax Evasion Using the Randomized Response Technique, Advance Taxation, 13: 69-94.

Hyun, J.K. (2005). Tax compliance in Korea and Japan: Why are they different?".Policy Research Institute, Ministry of Finance, Japan.

Izedonmi,F.O.I.(2000). Introduction to Auditing, AmbikPress ,Benin City. Kaduna, Nigeria; Apani Publications.

Kiabel, B.D. (2013). The law and practice of taxation of individuals in Nigeria. A paper delivered at the executive conversion course (ECC) programme of the institute of certified public accountant of Nigeria (ICPAN) RSUST training centre, port Harcourt.

Kiabel, B.D. \&Nwikpasi, N.N. (2009).Selected Aspects of Nigerian Taxation, Port Harcourt: Mgbaa Commercial Enterprises.

Kiabel, B.D. and Nwokah, N.G. (2009)'Boosting Revenue Generation by States governments in Nigeria: The Tax Consultants option Revisited". European Journal of Social Sciences, 8(4): 532-539.

Kiabel, B.D. (2001). Tax incentives as a tool of economic development. A paper presented at the mandatory continuous professional education (MCPE) programme of the institute of certified public accountants of Nigeria (ICPAN), Port Harcourt.

Lewis, A. (2013). The social psychology of taxation.British Journal of Social Psychology, 21(2), 151-158.

Long, S. B., \&Swingen, J. A. (1991). Taxpayer Compliance: Setting New Agendas for Research. Law \& Society Review, 25(3), 637-683.Malaysia. European Journal of Social Sciences, 24(1), 7-32.

Masud, A., Aliyu, A. A. \&Gambo, J. E (2014).Tax Rate and Tax Compliance in Africa.European Journal of Accounting, Auditing and Finance Research, 2(3), 22 - 30.

Measures.KPMG Advisory Services, Nigeria.

Mittone, L. (2006). Dynamic Behavior in Tax Evasion: An experimental Approach," The Journal of SocialEconomics, 35(5): 813-835.

OkolieO.A. (2002). The Nigeria audit practice: An Introduction Edo State, Nigeria.

Okon, E. (2012) Company Income Tax In Nigeria (unpublished Monograph) University of Port Harcourt.

Okonkwo, A. I. (2014). Critical evaluation of tax audit and investigation processes in enhancing tax compliance: being a paper presented at the CITNMPTP in Uyo on October 8-9.

Okoye,A.E.(2006). Unity Value of Internal Audit Report to Management in Nigeria" GIMPA Journal of Leadership Management and Administration 4(1)92-101

Orewa ,G.O (1979) Taxation in West and Mid- Western Nigeria $2^{\text {nd }}$ Edition, Institute of Social and Economic 
Research, Ibadan, Nigeria.

Organization for Economic Cooperation and Development (2001).Compliance Measurements- Practice Note.

Orviska, M., \& Hudson, J. (2003).Tax evasion, civic duty and the law abiding citizen.European Journal of accounting 2(1).44-55.

Osiegbu, P.I., Onuorah, A.C. and Nnamdi, I. (2010).Public Finance: Theories and Practices, Asaba: C.M. Global Company Ltd.

Osuala, E.C (2005) Introduction to Research Methodology The Millennium Edition, Enugu, Nigeria, Cheston Agency Ltd.

Richardson, G. (2006). Determinants of tax evasion: a cross-country investigation". Journal of international Accounting, Auditing \& Taxation, 15: 150-169.

Richardson, G. (2006). The impact of tax fairness dimensions on tax compliance behaviourin an Asian Jurisdiction: The case of Hong Kong, The International Tax Journal, 32(1):29-42.

Ritsema, C.M., Thomas, D.W. \&Ferrier, G.D. (2003)."Economic and Behavioural Determinants of TaxCompany Ltd.

Sandmo, A. (2005). The theory of Tax evasion: A retrospective view, National Tax Journal, 53(4); $643-648$.

Sarker, T.K. (2003). Improving tax compliance in developing countries via self-assessments systems-what could Bangladesh learn from Japan", Asia-Pacific Tax Bulletin, 9(6).

Schmölders, G. (1959). Fiscal Psychology: A new branch of public finance. National Tax Journal, 12(4), 340345.

Soyinka, K. A., Jinadu, O., \& Sunday, O. M. (2016). Tax audit determinants and corporate tax compliance in Nigeria.The International Journal of Business \& Management, 4(5),95-99.

Soyode, L. \&Kajola, S.O (2006) Taxation Principals and Practice in Nigeria, Ibadan, Nigeria; Solicon Publishers.

Sparks, P., Hedderley, D., \& Shepherd, R. (1992).An investigation into the relationship between perceived control, attitude variability and the consumption of two common foods.European Journal of Social Psychology, 22(1), 55-71.

Torgler, B. (2005b). Tax morale in Latin America.Public Choice, 122(1-2), 133-157.

Torgler, B. (2007). Tax compliance and tax morale. Cheltenham: Edward Elgar Publishing Company.

Torgler, B. (2011). Tax Morale and Compliance: Review of Evidence and Case Studies for Europe". Policy Research Working Paper 5922, World Bank, Europe and Central Asia Region, Human Development Economics Unit.

Torgler, B., \& Schneider, F. (2002).Does culture influence tax morale.Evidence from different European countries.

Webley, P., Cole, M., \&Eidjar, O.-P. (2001). The prediction of self-reported and hypothetical tax-evasion: Evidence from England, France and Norway. Journal of Economic Psychology, 22(2), 141-155.

Wenzel, M. (2004).The social side of sanctions: personal and social norms as moderators of deterrence, Law and Human Behaviour, 28: 547-567.

Wenzel, M. (2004).An analysis of norm processes in tax compliance, Journal of Economic Psychology, 25:213228.

Yamane \&Yaro (1967) Statistics: An Introductory Analysis, 2nd Edition, New York; Harper and Row.

Yongzhi, N. (2005), Tax Audit Impact on Voluntary Compliance. Economics Journal, 93 - 107.

Zahid, I. (2012). Compliance perceptions survey - small and medium sized enterprises and individuals. 